\title{
Effects of 2,4-D on the germination of megaspores and initial development of Regnellidium diphyllum Lindman (Monilophyta, Marsileaceae)
}

\author{
Cassanego, MBB. ${ }^{\mathrm{a}}$, Droste, $A .^{\mathrm{b}}$ and Windisch, $P G^{\mathrm{c}}{ }^{\mathrm{c} *}$ \\ aPrograma de Pós-Graduação em Biologia, Universidade do Vale do Rio dos Sinos - Unisinos, \\ Av. Unisinos, 950, CEP 93022-000, São Leopoldo, RS, Brazil

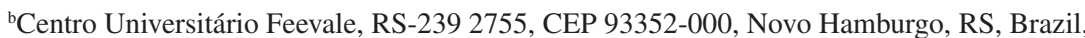 \\ Universidade do Vale do Rio dos Sinos - Unisinos, \\ Av. Unisinos, 950, CEP 93022-000, São Leopoldo, RS, Brazil \\ 'Programa de Pós-Graduação em Botânica, Universidade Federal do Rio Grande do Sul - UFRGS, \\ Av. Bento Gonçalves, 9500, CEP 91501-970, Porto Alegre, RS, Brazil \\ *e-mail: pteridos@gmail.com
}

Received September 30, 2008 - Accepted December 9, 2008 - Distributed May 31, 2010

(With 3 figures)

\begin{abstract}
Regnellidium diphyllum is considered as endangered, occurring in the State of Rio Grande do Sul, Brazil, and a few adjoining localities in Uruguay, Argentina and the State of Santa Catarina. It grows in wetlands frequently altered for agricultural activities. Herbicides based on 2,4-dichlorophenoxyacetic acid (2,4-D) are widely used in these fields. The effects of 2,4-D on the germination of megaspores and initial sporophytic development of $R$. diphyllum were investigated. Six concentrations of 2,4-D $\left(0.32 ; 0.64 ; 1.92 ; 4.80 ; 9.60\right.$ and $\left.19.20 \mathrm{mg} \cdot \mathrm{L}^{-1}\right)$, and the control $\left(0.00 \mathrm{mg} . \mathrm{L}^{-1}\right)$, were tested in vitro, using Meyer's medium. Cultures were maintained in a growth chamber at $24 \pm 1{ }^{\circ} \mathrm{C}$, under artificial light with nominal irradiance of $110 \mu \mathrm{mol} . \mathrm{m}^{-2} / \mathrm{s}$ and 16 hours photoperiod. Megaspore germination was lower at 9.60 and $19.20 \mathrm{mg} . \mathrm{L}^{-1}$ of 2,4-D (56 and 48\%, respectively), compared with the control (68\%). Herbicide concentrations of up to $1.92 \mathrm{mg} . \mathrm{L}^{-1}$ did not significantly decrease the number of sporophytes formed. At $19.20 \mathrm{mg} . \mathrm{L}^{-1}$, no sporophytes were formed. The lengths of the primary root, primary and secondary leaves were greater at concentrations of 0.32 and $0.64 \mathrm{mg} . \mathrm{L}^{-1}$ of 2,4-D. Low concentrations of 2,4-D do not affect germination rates and initial development of R. diphyllum in a significant way. However, higher concentrations (9.60 and $19.20 \mathrm{mg} . \mathrm{L}^{-1}$ ) affect substantially the germination of the megaspores and interfere with the establishment of the species.
\end{abstract}

Keywords: heterosporous fern, germination, herbicide, ecophysiology, conservation.

\section{Efeitos do 2,4-D sobre a germinação de megásporos e o desenvolvimento inicial de Regnellidium diphyllum Lindman (Monilophyta, Marsileaceae)}

\begin{abstract}
Resumo
Regnellidium diphyllum é considerada ameaçada, ocorrendo no Estado do Rio Grande do Sul, Brasil, e em algumas localidades vizinhas no Uruguai, na Argentina e no Estado de Santa Catarina. Cresce em áreas alagáveis, frequentemente alteradas para atividades agrícolas. Herbicidas baseados em ácido 2,4-diclorofenoxiacético (2,4-D) são largamente utilizados nestas plantações. Os efeitos do 2,4-D sobre a germinação de megásporos e o desenvolvimento esporofítico inicial de $R$. diphyllum foram investigados. Seis concentrações de 2,4-D $\left(0,32 ; 0,64 ; 1,92 ; 4,80 ; 9,60\right.$ e 19,20 mg.L $\left.\mathrm{L}^{-1}\right)$, além do controle $\left(0,00 \mathrm{mg} . \mathrm{L}^{-1}\right)$ foram testadas in vitro, utilizando meio de Meyer. As culturas foram mantidas em câmara de germinação a $24 \pm 1{ }^{\circ} \mathrm{C}$, sob luz artificial, com irradiância nominal de $110 \mu \mathrm{mol} . \mathrm{m}^{-2} / \mathrm{s}$ e fotoperíodo de 16 horas. A germinação de megásporos foi menor em 9,60 e 19,20 mg. $\mathrm{L}^{-1}$ de 2,4-D (56 e 48\%, respectivamente), comparada ao controle (68\%). Concentrações até $1,92 \mathrm{mg} \cdot \mathrm{L}^{-1}$ não diminuíram significativamente o número de esporófitos formados. Em 19,20 mg. $\mathrm{L}^{-1}$, não houve formação de esporófitos. Os comprimentos da raiz primária e das folhas primária e secundária foram maiores em concentrações de 0,32 e $0,64 \mathrm{mg} \cdot \mathrm{L}^{-1}$ de 2,4-D. Baixas concentrações de 2,4-D não afetam significantemente as taxas de germinação e o desenvolvimento inicial de $R$. diphyllum. Entretanto, maiores concentrações $\left(9,60\right.$ e 19,20 mg. $\left.\mathrm{L}^{-1}\right)$ afetam substancialmente a germinação de megásporos e interferem no estabelecimento da espécie.
\end{abstract}

Palavras-chave: filicínea heterosporada, germinação, herbicida, ecofisiologia, conservação. 


\section{Introduction}

The contamination of aquatic environments by pollutants such as heavy metals (Aravind and Prasad, 2005; Rodgher and Espíndola, 2008) and herbicides (Coler et al., 2005; Luo and Ikeda, 2007) is a major problem for the conservation of native animal and plant species. Wetlands receive inputs of herbicides commonly used to control weeds through direct deposit from aircraft spraying, lateral drift and runoff from fields. Required characteristics of modern herbicides include high effectiveness without causing environmental pollution or harmful effects, high activity, low toxicity, high selectivity and being non-persistent (Usui, 2001).

Rice is listed among the major food crops. Its yield is substantially reduced when weeds are not controlled. Of all the commonly used herbicides from the phenoxy class, 2,4-dichlorophenoxyacetic acid (2,4-D) most effectively controls broad-leaved plants when applied post-emergence. The herbicide presents auxinic activity and stimulates the production of ethylene and hydrogen cyanide, causing phytotoxicity (Usui, 2001).

Ecotoxicologic investigations have made it possible to evaluate the sensitivity and vulnerability of plant species to herbicides in aquatic systems (Fairchild et al., 1997; Forsyth et al., 1997; Wong, 2000; Santos and Banzatto, 2000; Sheffield, 2002; Aida et al., 2006; Luo and Ikeda, 2007). Herbicides can widely vary in the mode of action and effects across various phylogenetic groups of plants (Fairchild et al., 1997), indicating the potential use of aquatic plants as bioindicators. Plants differ in their capacity to transform and degrade herbicides, since different types and activities of enzymes work on this metabolism (Usui, 2001).

In Brazil, the National Environmental Council (CONAMA) allows a maximum limit of $4.0 \mu \mathrm{g} . \mathrm{L}^{-1}$ of $2,4-\mathrm{D}$ in water. Concentrations above these values are considered toxic to aquatic communities and improper for human use (MMA, 1986).

Regnellidium diphyllum Lindman, a heterosporous fern in the Marsileaceae family, has its distribution restricted to Southern Brazil and some adjoining localities in Uruguay and Argentina (Schultz, 1949; Alonso-Paz and Bassagoda, 2002). It grows in wetlands and the rhizome develops in the humid soil or mud. The plants are frequently subjected to flooding, with the leaf laminas above the water surface. In many areas, these wetlands have been transformed into rice fields and pastures, so that the plants in these localities are exposed to herbicides carried into the water or incorporated to the soil. Currently, the species is on the list of endangered species of the State of Rio Grande do Sul (SEMA, 2008).

It is important to understand the effect of herbicides on the non-target organisms in aquatic environments. Unfortunately, little is known about the effect of herbicides on aquatic pteridophytes (Keary et al., 2000; Santos and Banzatto, 2000; Sheffield, 2002; Luo and Ikeda, 2007) and no studies are available for their effects on $R$. diphyllum. The effects of 2,4-D on the germination of megaspores and initial sporophytic development of $R$. diphyllum were investigated.

\section{Material and Methods}

Mature sporocarps of Regnellidium diphyllum were obtained from different plants collected in the municipality of Triunfo (State of Rio Grande do Sul, Brazil) and kept at room temperature (about $25^{\circ} \mathrm{C}$ ) until the beginning of the experiment, one month later. Voucher specimens were placed in the Herbarium Anchieta (PACA, São Leopoldo, Brazil).

In a flow chamber, sporocarps were washed in tap water, rinsed with $70 \%$ ethanol solution and kept ten minutes in a $7 \%$ sodium hypochlorite solution, then washed in sterile distilled water and dried on sterile filter paper at room temperature. Fifteen sporocarps were cracked, thus liberating the spores, and the megaspores were separated manually from the microspores under a stereo-microscope. To assure homogeneous megaspore samples, the material from the different sporocarps was mixed. Apogamy is a normal occurrence in megagametophytes of R. diphyllum (Mahlberg and Baldwin, 1975), therefore only megaspores were used, in order to obtain uniform cultures, thus avoiding the mixture of sexual and apogamically formed sporophytes.

Meyer's solutions (Dyer, 1979) were prepared as culture media with 2,4-dichlorophenoxyacetic acid (2,4-D) at different concentrations: 0.00 (control), 0.32, $0.64,1.92,4.80,9.60$ and 19.20 mg.L ${ }^{-1}$. The $\mathrm{pH}$ was adjusted to 6.2 before autoclaving. Twenty five megaspores were placed in each glass vial $(4.5 \times 10 \mathrm{~cm})$ with $25 \mathrm{~mL}$ of the solution and there were six repetitions for each treatment. The cultures were maintained in a growth chamber at $24 \pm 1{ }^{\circ} \mathrm{C}$, under artificial light with nominal irradiance of $110 \mu \mathrm{mol} . \mathrm{m}^{-2} / \mathrm{s}$ and 16 hours photoperiod. The lowest concentration of 2,4-D $\left(0.32 \mathrm{mg} . \mathrm{L}^{-1}\right)$ was based on the commercial product DMA 806 BR (Dow AgroSciences Industrial Ltda.), an aqueous solution containing 806 g.L. $\mathrm{L}^{-1}$ 2,4-D. The manufacturer recommends the application of $1.2 \mathrm{~L}$ per hectare of cultivated rice (967.2 g.ha $^{-1}$ ). Considering the occasional partial submersion of $R$. diphyllum plants in water of up to ca. $30 \mathrm{~cm}$ this would correspond to a cover of three million litres of water per hectare. In one litre of culture medium, the equivalent concentration of 2,4-D would be $0.32 \mathrm{mg} . \mathrm{L}^{-1}$. Higher concentrations tested would represent herbicide applications in small water bodies, or additional input through other means.

After seven days of culture, data were collected weekly for a total of five weeks of observation. In order to document the development of the sporophytes, one individual was taken at random from each replicate, in a laminar flux chamber, at the end of the first and last week. The samples were photographed, measured for the length of the primary root and the length of the primary and secondary leaves, and then fixed in $70 \%$ ethanol. 
After five weeks, the germinated megaspores and the megagametophytes presenting sporophytes were counted. For each treatment the total number of leaves was counted for one individual from each repetition, totalising six individuals per treatment. Megaspores presenting at least the initial globose green structure with a crown of rhizoids were considered as germinated. Morphological details of sporophyte development under different concentrations were recorded.

Megaspore germination and sporophyte formation rates were transformed into percentages. The normality and homogeneity of the germination rates were verified using the Wilk-Shapiro and the Levene tests. The One-Way ANOVA test was applied to the data that conformed to normality and homogeneity. The difference between averages was verified using the Tukey test with $\alpha=0.05$ probability. The Kruskal-Wallis test was applied to data that did not conform and differences between averages were verified using the Dunn test with $\alpha=0.05$ probability (Zar, 1999). Linear regression analysis was applied to estimate the relation between the 2,4-D concentrations and the respective number of leaves formed. The analyses were conducted using the Systat version 10.2 for Windows (2000) at the Universidade do Vale do Rio dos Sinos.

\section{Results}

The application of 2,4-D at high concentrations (9.6 and 19.2 mg.L ${ }^{-1}$ ) negatively influenced the germination capacity of $R$. diphyllum, while concentrations up to $4.80 \mathrm{mg} . \mathrm{L}^{-1}$ did not differ statistically from the control (Figure 1).

A significant negative influence was observed in the formation of sporophytes in the treatments of 4.80 and $9.60 \mathrm{mg} . \mathrm{L}^{-1}$ of $2,4-\mathrm{D}$ (respectively 55 and $31 \%$ of the megagametophytes forming sporophytes). Lower concentrations up to $1.92 \mathrm{mg} . \mathrm{L}^{-1}$ did not present significant differences in relation to the control, and also presented

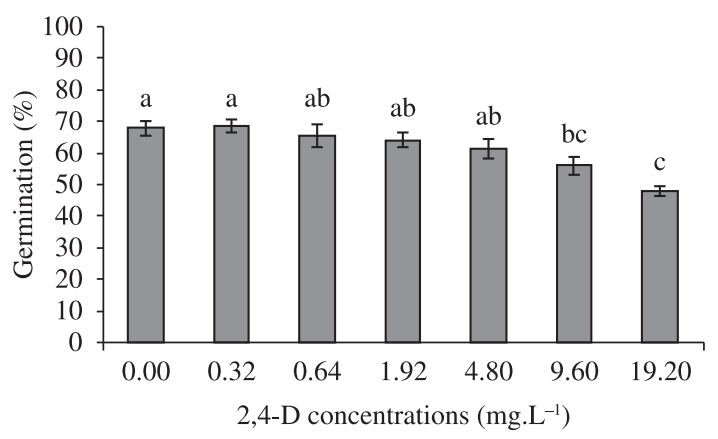

Figure 1. Germinability of Regnellidium diphyllum Lindman megaspores in different 2,4-D concentrations after five weeks in culture (ANOVA test, $\mathrm{F}=7.75$, d.f. $=6,35, \mathrm{P}=0.001$ ). $(\mathrm{F}=\mathrm{F}$ value; d.f $=$ degree of freedom; $\mathrm{P}=$ probability $)$. Means with different letters are significantly different by the Tukey test, $\alpha=0.05$. Error bars indicate standard error. the highest averages in sporophyte formation. No sporophytes were formed at $19.20 \mathrm{mg} . \mathrm{L}^{-1}$, the highest concentration tested (Figure 2).

The length of the primary root of the sporophytes was affected by 2,4-D (Table 1). After one week in culture, a significant reduction in root growth compared to the control was observed at the concentration of $9.60 \mathrm{mg} . \mathrm{L}^{-1}$. After five weeks, these differences could still be observed in concentrations of $1.92 \mathrm{mg} . \mathrm{L}^{-1}$ and higher.

The development of the primary leaf was also affected by the presence of 2,4-D (Table 1). At the end of the first week, the growth of the primary leaf was significantly reduced when compared with the control at 2,4-D concentrations of $4.80 \mathrm{mg} \cdot \mathrm{L}^{-1}$ and higher. After five weeks, the primary leaf was significantly shorter at $1.92 \mathrm{mg} . \mathrm{L}^{-1}$ and higher concentrations.

The development of the first secondary leaf was strongly affected by 2,4-D after one week and five weeks in culture (Table 1). Usually it is formed after one week in culture (Vianna, 1973). However, in the treatments with concentrations of $4.80 \mathrm{mg} . \mathrm{L}^{-1}$ of $2,4-\mathrm{D}$ and higher, the secondary leaf was not formed at all in the first week. At the highest concentration under which sporophyte formation occurred ( $\left.9.60 \mathrm{mg} . \mathrm{L}^{-1}\right)$, no secondary leaves developed even after five weeks in culture.

There was a significant negative relation between the 2,4-D concentrations and the number of leaves formed after five weeks, as an observable linear regression (Figure 3 ). In $0.32 \mathrm{mg} . \mathrm{L}^{-1}$ of the herbicide, the sporophytes formed up to five leaves, whereas concentrations of $0.64 \mathrm{mg} . \mathrm{L}^{-1}$ and higher caused a gradual decrease of the maximum number of leaves formed, declining from three to one. The mean number of leaves formed in each treatment was situated near to the regression line. No leaves were formed in the highest 2,4-D concentration tested. All other treatments with the herbicide presented smaller numbers of leaves than the control.



Figure 2. Regnellidium diphyllum Lindman sporophyte formation in different 2,4-D concentrations after five weeks in culture (Kruskal-Wallis test, $\mathrm{H}=33.99$, d.f. $=6,35, \mathrm{P}=$ 0.001). $(\mathrm{H}=\mathrm{H}$ value; d.f $=$ degree of freedom; $\mathrm{P}=$ probability). Means with different letters are significantly different by the Dunn test, $\alpha=0.05$. Error bars indicate standard error. 
Cassanego, MBB, Droste, A. and Windisch, PG.

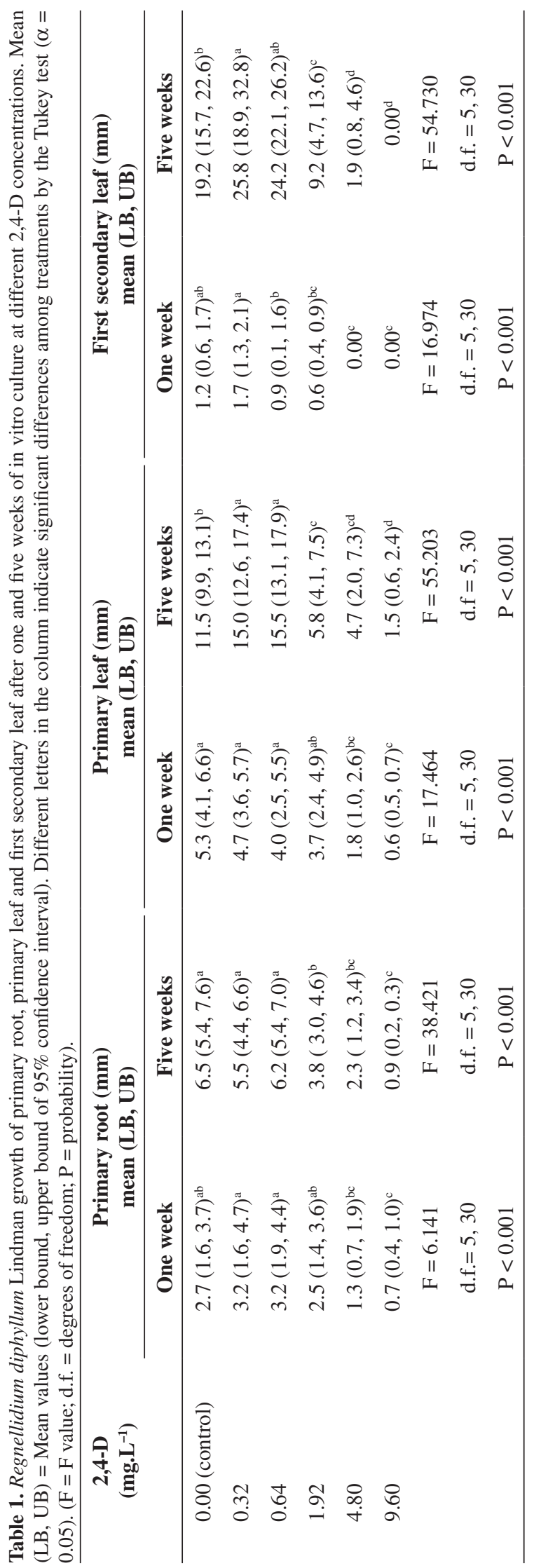




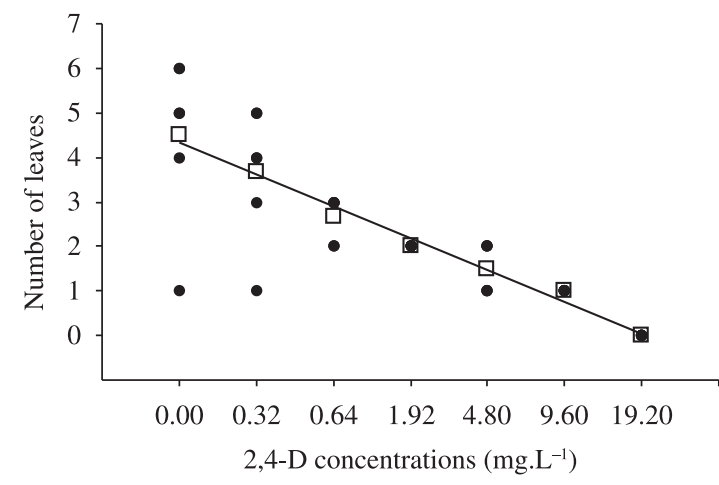

Figure 3. Relation between the number of leaves of Regnellidium diphyllum Lindman sporophytes and different 2,4-D concentrations after five weeks of culture $\left(r^{2}=0.54\right.$, $\mathrm{F}=47.05$, d.f. $=1,40, \mathrm{P}<0.001)$. $\left(\mathrm{r}^{2}=\right.$ squared multiple $\mathrm{r}$ value; d.f = degree of freedom; $\mathrm{P}=$ probabiity). Black circles represent one or more of the six replicates; white squares represent the mean number of leaves in each treatment.

\section{Discussion}

The percentage of germinated megaspores in the culture medium with $0.32 \mathrm{mg} . \mathrm{L}^{-1}$ of $2,4-\mathrm{D}$ was $68.5 \%$, a similar percentage of the control, which presented $68 \%$ of germination. From $0.64 \mathrm{mg} . \mathrm{L}^{-1}$ onwards, the increase of 2,4-D concentration was accompanied by the gradual decrease of germination percentage, although up to $4.80 \mathrm{mg} . \mathrm{L}^{-1}$, no statistically significant differences were observed when compared with the control group. In the highest 2,4-D concentration tested (19.2 mg. $\left.\mathrm{L}^{-1}\right)$, less than $50 \%$ of germination was obtained.

The 2,4-D is an auxin simulator molecule that is designed and used as a selective herbicide for broadleaved plants, i.e. dicots (Fairchild et al., 1997). At low concentrations, it stimulates growth of plant cells and on interacting with endogenous hormones like ethylene, giberellic acid, abscisic acid and even auxins, 2,4-D can break seed dormancy, stimulating the germination process (Brady and McCourt, 2003). On the other hand, high concentrations or successive applications of this herbicide retarded or even inhibited the germination of dicotyledonous and monocotyledonous seeds (Usui, 2001).

After three days of megaspore culture, the first sporophytes could be observed. Vianna (1973) verified that the first sporophytic structures emerged from the megagametophytes of Regnellidium diphyllum around the first week of in vitro culture. In the present experiment, no sporophytes were obtained at $19.20 \mathrm{mg} \cdot \mathrm{L}^{-1}$ of 2,4-D, and at $9.60 \mathrm{mg} . \mathrm{L}^{-1}$ only $31.4 \%$ of the megagametophytes formed sporophytes. Furthermore, $4.80 \mathrm{mg}$. $\mathrm{L}^{-1}$ and higher concentrations caused abnormal structures. Sporophytes obtained from the treatments without 2,4-D (control) and with the lowest 2,4-D concentration $\left(0.32 \mathrm{mg} . \mathrm{L}^{-1}\right)$ formed the largest number of leaves (respectively, six and five leaves) after five weeks of in vitro culture. The gradual decrease of the number of leaves formed on the sporophytes, the abnormal tissue proliferation and the chlorosis and necrosis of leaf and root tissues were related to higher concentrations of 2,4-D, specially 4.80 to $9.60 \mathrm{mg} . \mathrm{L}^{-1}$. The length of the primary and secondary leaves of $R$. diphyllum in the treatments with minor $2,4-\mathrm{D}$ concentration $\left(0.32 \mathrm{mg} . \mathrm{L}^{-1}\right)$ was significantly higher when compared with the control group at the end of the experiment. Nevertheless, concentrations from 1.92 to $9.60 \mathrm{mg} . \mathrm{L}^{-1}$ caused minor root and primary leaf growth, however no secondary leaves were grown on $9.60 \mathrm{mg} . \mathrm{L}^{-1}$. As a systemic herbicide, at high concentrations, 2,4-D translocates throughout the whole plant, causing biochemical disturbance in cells and disorganised synthesis of nucleic acids and proteins (Grossmann, 2003).

Studies have analysed the susceptibility of ferns to rice herbicides (Sheffield, 2002; Aida et al., 2006; Luo and Ikeda, 2007). However, no tests were performed on the toxicity of 2,4-D or other herbicides on R. diphyllum, so that no direct comparisons are possible. Wong (2000) tested the concentrations of 0.02 to $200 \mathrm{mg} . \mathrm{L}^{-1}$ of the herbicides 2,4-D, glyphosate and paraquat on the growth and chlorophyll-a synthesis of the green algae Scenedesmus quadricauda (Turpin) Brébisson. The author verified that low concentrations of 2,4-D (0.02 and $\left.0.2 \mathrm{mg} . \mathrm{L}^{-1}\right)$ stimulated the two tested variables, while $200 \mathrm{mg} . \mathrm{L}^{-1}$ of this herbicide inhibited completely the algal growth and chlorophyll- $a$ production.

Forsyth et al. (1997) found that a concentration of $0.01 \mathrm{mg} . \mathrm{L}^{-1}$ of $2,4-\mathrm{D}$ stimulated the vegetative growth while $0.1 \mathrm{mg} . \mathrm{L}^{-1}$ reduced the size to $40 \%$ of the aquatic macrophytes Potamogeton pectinatus L. and Myriophyllum sibiricum Kom. In another experiment, Santos and Banzatto (2000) observed that 6.25, 12.5 and $25 \mathrm{mg} . \mathrm{L}^{-1}$ of 2,4-D had no toxic effects on two other aquatic macrophytes, Spirodela punctata (G. Mey.) C.H. Thomps. and Salvinia minima Baker, and only Spirodela punctata was sensitive to the concentration of $50 \mathrm{mg} . \mathrm{L}^{-1}$. Species of the aquatic fern Salvinia, mainly S. minima and S. molesta, are frequently found in environments also preferred by R. diphyllum. According to Santos and Banzatto (2000), S. minima showed tolerance to 2,4-D up to $50 \mathrm{mg}$. $\mathrm{L}^{-1}$, while in the present study the concentrations of $4.80 \mathrm{mg} . \mathrm{L}^{-1}$ and higher were toxic to $R$. diphyllum, showing that this fern is more susceptible to this herbicide than $S$. minima. This could be an obstacle to the establishment and permanence of $R$. diphyllum in habitats exposed to 2,4-D contamination.

Alterations of natural habitat conditions, even in preserved areas, the destruction of wetlands due to expansion of urban areas and the establishment of pastures and plantations where 2,4-D or other chemicals are used, are major problems to be considered in relation to the conservation of the currently vulnerable $R$. diphyllum.

Acknowledgements - The authors are grateful to the Universidade do Vale do Rio dos Sinos for the use of laboratories and the scholarship to the first author, to the Centro Universitário Feevale, to the Universidade Federal do Rio Grande do Sul and 
to the Conselho Nacional de Desenvolvimento Científico e Tecnológico (CNPq) for support and grants. Dr. Joanne Sharpe provided welcome suggestions for the preparation of the text.

\section{References}

AIDA, M., IKEDA, H., ITOH, K. and USUI, K., 2006. Effects of five rice herbicides on growth of two threatened aquatic ferns. Ecotoxicology and Environmental Safety, vol. 63, no. 3, p. $463-468$.

ALONSO-PAZ, E. and BASSAGODA, MJ., 2002. Revisión de las Marsileaceae del Uruguay y primera cita de Pilularia americana A. Braun. Comunicaciones Botanicas: Museos Nacionales de Historia Natural y Antropologia, vol. 125, no. 6, p. 1-8.

ARAVIND, P. and PRASAD, MNV., 2005. Cadmium-Zinc interactions in a hydroponic system using Ceratophyllum demersum L.: adaptative ecophysiology, biochemistry and molecular toxicology. Brazil. Journal of Plant Physiology, vol. 17 , no. 1, p. 3-20.

BRADY, SM. and McCOURT, P., 2003. Hormone Cross-Talk in seed dormancy. Journal of Plant Growth Regulation, vol. 22, no. 1 , p. 25-31.

COLER, RA., COLER, RR., FELIZARDO, EKG. and WATANABE, T., 2005. Applying weight gain in Pomacea lineata (Spix 1824) (Mollusca: Prosobranchia) as a measure of herbicide toxicity. Revista Brasileira de Biologia $=$ Brazilian Journal of Biology, vol. 65, no. 4, p. 617-623.

DYER, AF., 1979. The culture of fern gametophytes for experimental investigation. In DYER, AF. (Ed.). The Experimental Biology of Fern. London: Academic Press. p. 253-291.

FAIRCHILD, JF., RUESSLER, DS., HAVERLAND, PS. and CARLSON, AR., 1997. Comparative sensitivity of Selenastrum capricornutum and Lemna minor to sixteen herbicides. Archives of Environmental Contamination and Toxicology, vol. 32, no. 4, p. 353-357.

FORSYTH, DJ., MARTIN, PA. and SHAW, GG., 1997. Effects of herbicides on two submersed aquatic macrophytes, Potamogeton pectinatus L. and Myriophyllum sibiricum Komarov, in a prairie wetland. Environmental Pollution, vol. 95, no. 2, p. 259-268.

GROSSMANN, K., 2003. Mediation of herbicide effects by hormone interactions. Journal of Plant Growth Regulation, vol. 22 , no. 4 , p. 109-122.
KEARY, IP., THOMAS, C. and SHEFFIELD, E., 2000. The effects of the herbicide asulam on the gametophytes of Pteridium aquilinum, Cryptogramma crispa and Dryopteris filix-mas. Annals of Botany, vol. 85, no. B, p. 47-51.

LUO, XY. and IKEDA, H., 2007. Effects of four rice herbicides on the growth of an aquatic fern, Marsilea quadrifolia L. Weed Biology and Management, vol. 7, no. 4, p. 237-241.

MAHLBERG, PG. and BALDWIN, M., 1975. Experimental studies on megaspore viability, partenogenesis and sporophyte formation in Marsilea, Pilularia and Regnellidium. Botanical Gazette, vol. 136, no. 3, p. 269-273.

Ministério do Meio Ambiente - MMA, 1986. Resolução CONAMA n ${ }^{\circ} 20$, de 18 de junho de 1986. Dispõe sobre a classificação das águas e estabelece os limites máximos das substâncias potencialmente prejudiciais. Diário Oficial da União, Poder Executivo, Brasília, DF, 30 de julho de 1986. Seção II, p. 8.

RODGHER, S. and ESPÍNDOLA, ELG., 2008. The influence of algal densities on the toxicity of chromium for Ceriodaphnia dubia Richard (Cladocera, Crustacea). Revista Brasileira de Biologia $=$ Brazilian Journal of Biology, vol. 68, no. 2, p. 341-348.

SANTOS, DMM. and BANZATTO, DA., 2000. Efeitos de herbicidas nas plantas aquáticas Spirodela punctata (G.F.W. Meyer) Thompson e Salvinia minima Baker. Ecossistema, vol. 25 , no. 1 , p. 69-75.

SCHULTZ, AR., 1949. Contribuições ao conhecimento de Regnellidium diphyllum Lindman. Lilloa, vol. 17, p. 139-144.

Secretaria do Meio Ambiente - SEMA, 2008. Espécies da flora ameaçadas de extinção do Rio Grande do Sul. Porto Alegre.

SHEFFIELD, E., 2002. Effects of asulam on non-target pteridophytes. Fern Gazette, vol. 16, no. 6-8, p. 377-382.

USUI, K., 2001. Metabolism and selectivity of rice herbicides in plants. Weed Biology and Management, vol. 1, no. 3, p. 137-146.

VIANNA, EC., 1973. Observações sobre o desenvolvimento morfológico do esporófito de Regnellidium diphyllum Lindm. (Hidropteridineae). Iheringia Série Botânica, vol. 18, p. 27-37.

ZAR, JH., 1999. Biostatistical analyses. $4^{\text {th }}$ ed. Upper Saddle River: Prentice-Hall. 931 p.

WONG, PK., 2000. Effects of 2,4-D, glyphosate and paraquat on growth, photosynthesis and chlorophyll- $a$ synthesis of Scenedesmus quadricauda Berb 614. Chemosphere, vol. 41, no. 1 , p.177-182. 